\title{
THE TRAFFIC ENGINEERING APPROACH TO PROBLEMS OF SEA WATERWAY SYSTEM DESIGN \\ PROBLEMY PROJEKTOWANIA SYSTEMU MORSKICH DRÓG WODNYCH W UJĘCIU INŻYNIERII RUCHU
}

\author{
Stanisław Gucma \\ Maritime University of Szczecin \\ Wały Chrobrego 1-2, 70-500 Szczecin, Poland \\ e-mail: s.gucma@am.szczecin.pl
}

\begin{abstract}
The article deals with some problems that designers of sea waterways encounter, i.e.: interrelations between parameters of waterway, ships and positioning systems used, selection of position determination systems depending on ship's operating conditions on sea waterways, and the optimization of waterway parameters.
\end{abstract}

Keywords: marine traffic engineering, waterways, navigation systems

Streszczenie: W artykule zostana przedstawione wybrane problemy projektowania systemu morskich dróg wodnych, takie jak: wzajemna zależność parametrów dróg wodnych, statków $i$ stosowanych systemów pozycjonowania; dobór systemów pozycjonowania $w$ zależności od warunków eksploatacji statków na morskich drogach wodnych; optymalizacja parametrów dróg wodnych.

Słowa kluczowe: inżynieria ruchu morskiego, drogi wodne, systemy nawigacyjne 
The traffic engineering approach to problems of sea waterway system design Problemy projektowania systemu morskich dróg wodnych w ujęciu inżynierii ruchu

\section{Introduction}

Waterway design or modernization at the stage where safe parameters are determined is strictly connected with the design of position determination systems for the waterway being designed. Therefore, this stage is often called waterway system design [Gucma S. 2012].

Waterway (fairway) system design can be divided into the following working stages:

Defining the waterway operating conditions, including:

- determination of quantitative and qualitative composition of expected vessel traffic, division into characteristic groups, determination of 'maximum size' ships;

- determination of allowable hydrometeorological conditions for each group;

- determination of general guidelines for traffic control and manoeuvring principles for each group of ships.

Preliminary determination of waterway parameters, consisting of:

- division of a waterway into sections characterized by different types of manoeuvres performed therein, and different hydrometeorological conditions;

- determination of a safe waterway depth within each section and preliminary determination of parameters of navigable areas.

Design of a position determination system and optimization of navigable areas parameters, with these components:

- requirements to be met by position determination systems;

- choice of the type of systems of position determination for each waterway section for various characteristic ship groups and various hydrometeorological conditions;

- determination of navigational system parameters within each waterway section;

- determination of safe manoeuvring areas for ships under consideration at an assumed confidence level.

- determination of optimal parameters of navigable areas for the assumed operating conditions.

Navigational systems are designed according to the following algorithm [Gucma S. 2004]:

1. Navigational systems (position determination systems ) in a given waterway are designed separately for each ship size group.

2. Design of these systems should be commenced from the largest ships, as it often turns out that requirements for systems serving small ships are satisfied by systems intended for large ships [Gucma S. 2004].

3. Position determination systems are designed for three visibility conditions:

- daylight (good visibility), 
- night-time (good visibility),

- poor visibility.

It should be noted that operating guidelines may restrict the conditions designed for particular ship size groups, for example:

- specific size ships will navigate only at daylight,

- navigation of vessels along a given waterway may only be conducted at good visibility.

4. Position determination systems for specified visibility conditions have to be doubled, otherwise a failure of one system poses a risk of navigational accident (a number of failures may occur at the same time). For each of the three visibility conditions two navigational systems have to be designed:

- primary system,

- additional system.

5. Designed position determination systems of a vessel at a preset waterway section have to satisfy these criteria:

- availability,

- reliability,

- accuracy.

The availability of the vessel position determination system depends on the ownership status and prevailing hydrometeorological conditions:

- the former may refer to such occurrences as the disconnection of navigational lights by their owner.

- hydrometeorological conditions in which certain position determination systems are not available, refer to: restricted visibility $(s<2 \mathrm{Nm})$, at which terrestrial (optical) methods) are not available, or ice situation, where seamarks are normally removed.

- extreme hydrometeorological conditions, in which the whole waterway system is inaccessible for a given ship, are defined by vessel operating conditions within the waterway under consideration, e.g. exceeded wind speed or wave height.

The reliability of position determination of a vessel is its ability to obtain a position with specific accuracy. This technical reliability is estimated by the intensity of failures of system components. Defects of the system components decrease the assumed accuracy or make position determination impossible.

The probability of system component reliability is calculated by using the failure intensity function $\lambda(t)$ at instant $t$, the density function of the failure under a condition that till that instant there was no failure [Gucma S. 2001]. The reliability of satellite or radionavigation methods (e.g. pilot navigation system) depends on technical faults of the system (its software and hardware). The reliability of optical methods may be affected by seamarks getting adrift or failure of lights in the night. The reliability of radar methods may be affected by floating 
The traffic engineering approach to problems of sea waterway system design Problemy projektowania systemu morskich dróg wodnych w ujęciu inżynierii ruchu

seamarks adrift (technical reliability due to radar fault will not fail as the ship is equipped with two radars working on hot redundancy basis).

It is assumed in the considered design method that the width of safe manoeuvring area is described by the function of position determination accuracy, thus by the parameters of the systems. Therefore,

$$
d=f\left(d_{n}\right)
$$

so

$$
d=f\left(N_{i}\right)
$$

where

$d \quad$ - width of safe manoeuvring area,

$d_{n}$ - navigational component of safe manoeuvring area width,

$N_{i}$ - parameters of the position determination system.

The major issue to be solved in designing waterways and defining operating conditions is to assure properly high level of manoeuvring safety in fairways. This task comes down to the determination of navigable area parameters within waterways and parameters of navigational systems used therein for manoeuvring. The vessel can manoeuvre safely only within an area that at each point satisfies the condition of required (safe) depth. Such area is a navigable area that can be represented as an area $\mathbf{D}$ of a set of points satisfying the condition of required depth at an instant $t$. A safe depth at the design stage or during waterway modernization is usually determined by the constant underkeel clearance method.

The vessel performing a given manoeuvre within a navigable area during that manoeuvre occupies a certain area defined by its subsequent positions in the area. That area is called the safe manoeuvring area [Gucma S. 2001].

This author will present two methods for safe manoeuvring area parameters determination (safe fairway widths) and their position determination systems. These are:

- deterministic-probabilistic method,

- navigational risk method.

\section{The deterministic-probabilistic method for the determination of safe manoeuvring area width in fairways}

The ship performing a given manoeuvre within a navigable area during that manoeuvre occupies a certain area defined by its subsequent position in the area. The parameters of this area have a random character and depend on a number of various factors. The area, calculated at a certain level of confidence, is referred to as safe manoeuvring area $\mathbf{d}(1-\alpha)$ [Gucma S. et al. 2008].:

With this definition of the safe manoeuvring area it can be represented as an area $\mathbf{d}_{\mathrm{ijk}}$ (set of points), and the basic condition of navigational safety can be written as follows [Gucma S. 2004]: 


$$
\overbrace{p(x, y) \in \mathbf{D}(t)}^{\mathbf{d}_{\mathrm{ijk}}(1-\alpha) \subset \mathbf{D}(t)} h(x, y, t) \geq T(x, y, t)+\Delta(x, y, t)
$$

where

$$
\begin{aligned}
\mathbf{D}(t) \quad- & \text { navigable area (the safe depth condition is satisfied at } \\
& \text { instant } t), \\
\mathbf{d}_{\mathrm{ijk}}(1-\alpha)- & \text { safe manoeuvring area at confidence level } 1-\alpha .
\end{aligned}
$$

The sets of points of a navigable area $\mathbf{D}(t)$, and those of safe manoeuvring area $\mathbf{d}_{\mathrm{ijk}}(1-\alpha)$ can be identified as areas with specific linear parameters. In various types of waterways the basic linear parameter that is critical for the safety of a manoeuvre to be performed is their width. Therefore, the condition of performing a given manoeuvre safely can be transformed to this form:

$$
D(t)_{i j k} \geq d_{i j k}(1-\alpha)
$$

where

$D(t)_{i j k} \quad$ - width of navigable area available at instant $t$ (navigable area available for $i$-th ship for $j$-th type of manoeuvre performed in $k$-th hydrometeorological conditions);

$d_{i j k}(1-\alpha)$ - width of safe manoeuvring area of $i$-th ship, for $j$-th type of manoeuvre performed in $k$-th hydrometeorological conditions at confidence level $(1-\alpha)$.

What follows from the above considerations is that the assurance of safe navigation in waterways is strictly connected with a choice of appropriate, i.e. safe confidence level when parameters of the waterways and navigational systems are determined. The deterministic-probabilistic method devised at the Institute of Marine Navigation, Maritime University of Szczecin (Gucma's method) was used for the determination of safe manoeuvring area at a given confidence level. The method utilizes the PIANC method for the determination of manoeuvring component of an area [Gucma S. 2001], in which the manoeuvring component of safe width of manoeuvring area $\left(d_{m}\right)$ is defined deterministically, while the navigational component of safe width of manoeuvring area has a probabilistic character and is determined at a definite confidence level as $d_{n}(1-\alpha)$. In the method, the fairway navigation safety condition (for $i$-th ship performing $i$-th manoeuvre in $k$-th navigational conditions) can be written as follows:

$$
D(t)_{i j k} \geq d_{i j k}(1-\alpha)=d_{m_{i j k}}+2 d_{n_{i j k}}(1-\alpha)+2 d_{r_{i j k}}
$$

where

$d_{r}-$ reserve of the manoeuvring area width. 
The traffic engineering approach to problems of sea waterway system design Problemy projektowania systemu morskich dróg wodnych w ujęciu inżynierii ruchu

The determination of safe manoeuvring area parameters requires that confidence levels be established for position determination for each of the navigational method (system) used. To establish the confidence levels, we have to take into account the following:

- parameters and characteristics of each position determination method (system);

- ship's operating conditions on the waterway under consideration;

- navigational safety (risk) of the manoeuvring ship [Gucma S. et al. 2008].

Designers of position determination systems for waterways usually assume the following confidence levels [Gucma S. 2012]:

- primary systems:

$1-\alpha=0.997-$ ships with dangerous goods and those sailing at high speed, V>12 knots;

$1-\alpha=0.95-$ other ships;

- additional systems:

$1-\alpha=0.95$

\section{Determination of the waterway safe manoeuvring area by using the navigational risk method}

Navigational safety is a concept comprising all issues connected with smooth conduct of a ship along the examined waterway. The term accident is understood herein as a navigational or manoeuvring accident, such as:

- grounding (broadly understood as unintended contact of the ship's hull, rudder or propeller with the seabed);

- damage to the hull due to ship's contact with the shore (ship's impact on the shore when the water depth exceeds the ship's draft);

- damage to a marine structure due to ship's direct contact;

- damage to a floating seamark;

- collision with another ship in the area.

The navigation safety in restricted areas can be presented as a function [Gucma S. 2001]:

where

$$
P_{b}=f\left(A_{b}, S_{b}, N_{b}, H_{b}, M_{b}, I_{b}, R_{b}\right)
$$

$P_{b} \quad-$ navigation safety assessment indicator,

$A_{b}$ - area parameters,

$S_{b}-$ vessel parametes,

$N_{b}$ - parameters of position determination systems,

$H_{b}$ - hydrometeorological parameters,

$M_{b}$ - parameters of manoeuvre performed,

$I_{b} \quad$ - parameters of traffic intensity,

$R_{b} \quad$ - Parameters of traffic control system. 
The function of navigation safety is a variable dependent on independent variables $A_{i}, S_{i}, N_{i}, H_{i}, M_{i}, I_{i}, R_{i}$. These, in turn, represent a number of factors describing the system: vessel - area - position determination system - prevailing hydrometeorological conditions - traffic intensity - traffic control system - manoeuvring tactics.

In order to determine the influence of the variables $A_{i}, S_{i}, N_{i}, H_{i}, M_{i}, I_{i}, R_{i}$ on navigation safety, we have to assume the numerical indicator $P_{i}$. This indicator quantitatively defines the navigation safety in restricted areas. At present research is in progress aiming at making this indicator applicable to all types of restricted areas and manoeuvres performed therein. The ability to estimate such indicator will enable unequivocal quantitative assessment of the navigation safety in restricted areas. One such indicator, or criterion, increasingly used worldwide for navigational safety assessment is navigational risk [Gucma L. 2009]. Navigational risk is a complex criterion of navigation safety assessment identified with a risk connected with the performance of certain manoeuvres in a given area.

Navigational risk is expressed as a product of accident probability and consequences the accident will cause. Additionally, the definition is supplemented with relative frequency of performing the examined manoeuvre. If we assume that an accident and its consequences are independent events, navigational risk can be presented as this product [Gucma S. 2001]:

where

$$
R=P_{A} S I_{R} \quad\left[\mathrm{rok}^{-1}\right]
$$

$P_{A}-$ probability of a given navigational accident during performance of a given manoeuvre,

$S$ - consequences that accident will cause,

$I_{R}$ - average yearly intensity (frequency) of performing a given manoeuvre [year ${ }^{-1}$.

Estimation of navigational risk consists in:

- identification of threats during a specific manoeuvre is being performed in a given area by a specific ship in $k$-th navigational conditions;

- calculations of the certain type accident probability while performing a $j$-th type manoeuvre in a given restricted area by an $i$-th type ship in $k$-th navigational conditions;

- estimation of the consequences of a certain type accident that occurred due to performing a $j$-th type manoeuvre in a given restricted area by an $i$-th type ship in $k$-th navigational conditions.

Based on the definition of navigational risk the condition of safe navigation has beed determined:

where

$$
R_{a k c} \geq R
$$

$R_{a k c}-$ acceptable navigational risk. 
The traffic engineering approach to problems of sea waterway system design Problemy projektowania systemu morskich dróg wodnych w ujęciu inżynierii ruchu

Identification and analysis of threats occurring in manoeuvring in fairways allow to formulate the basic assumption concerning accident consequences. Acceptable navigational risk for the examined accidents (threats) in fairways is determined for the assumption that there are no fatalities caused by such accident.

Knowing an acceptable risk and starting from this inequality:

and assuming that

$$
R_{a k c} \geq P_{A} S I_{R}
$$

where

$$
P_{A}=1-P_{n} P_{t}
$$

$P_{A}-$ probability of an accident,

$P_{n}-$ navigational reliability - probability of an accident-free performance of a manoeuvre,

$P_{t} \quad-$ technical reliability;

we can determine an allowable confidence level for the examined waterway system (fairway) [Gucma S. 2010]:

$$
1-\alpha \geq \frac{1-\frac{R_{a k c}}{S I_{R}}}{P_{t}}
$$

During a ship's manoeuvre such as passage along a fairway the prevailing threats are as follows:

- grounding (fairway underwater slope) or impact on shore element,

- collision with another ship in the fairway.

\section{Grounding in the fairway}

The primary threat ships face in the fairway is possible grounding by hitting a slope of the dredged fairway. The risk of such accident can be estimated using the concept of navigational risk.

The acceptable risk of performing a specific manoeuvre has been determined by identifying it with an acceptable number of accidents that occurred during such manoeuvres in one year. This assumption can be made for average accident consequences equalling one $\left(S_{s r}=1\right)$.

Navigational events, depending on their consequences, are of two types:

- incidents - consequences $\mathrm{S} \leq 1$,

- accidents - consequences $S>1$.

The elimination of incident consequences does not require special salvage operations, and quite often incidents are not reported to maritime administration or even the shipowner. To eliminate consequences of an accident, on the other hand, a rescue or salvage operation has to be organized. Research has shown that the ratio of accidents to the total number of incidents and accidents in a given area does not exceed $10 \%$ [Gucma S. 2001]. 
Dutch criteria of navigation safety on fairways (restricted waters) allow for not more than one accident in 237 years, which translates into 0.004 accident (grounding) per year. On the other hand, British criteria accept maximum 0.001 accident (grounding) in a year. [Gucma S. 2001].

Waterways are generally designed for a period of 50 years of operation, while ships are designed to serve for 15 years. However, the following facts should be considered:

- in the course of 50-100 year operation of a waterway it is modernized a few times; such modernization results from, among other reasons, the introduction of more advanced navigational systems, manoeuvring methods and ships;

- each new generation of ships (after 15 years) is better in terms of manoeuvring ability, navigational systems, technical reliability etc.

Taking the above facts into consideration, it has been found that there is no need to arbitrarily raise safety requirements. Therefore, the following criteria have been adopted for LNG tanker navigation safety along the approach channel. This refers to grounding, in which case vessel's hull does not sustain damage and LNG tanks remain tight:

- tidal areas the maximum of 0.004 accident per year;

- non-tidal areas the maximum of 0.007 accident per year.

\section{Collision with another ship in the fairway}

The assessment of risk of collision with another ship in the fairway is made similarly to that of risk of grounding, that is using the concept of navigational risk. The condition of navigational safety in the fairway is that

where:

$$
R_{a k c} \geq R
$$

$R \quad-$ navigational risk,

$R_{a k c} \quad-$ acceptable navigational risk.

Events here considered have been again divided into two types, depending on their consequences:

- accidents, where a rescue/salvage operation is required, or where there is a probability of fatalities;

- incidents, where a rescue/salvage operation is not required, and no fatalities occur.

An accident risk is denoted as $R_{c}$. Consequences of accidents satisfy this condition:

$$
S_{c}>1
$$

The risk of incidents is denoted as $R_{\mathrm{l}}$. Consequences of incidents $\left(S_{1}\right)$ may be smaller or greater than one. The elimination of incident consequences, where $S_{1} \leq 1$ does not call for organizing any rescue or salvage operations, and notably, in many 
The traffic engineering approach to problems of sea waterway system design Problemy projektowania systemu morskich dróg wodnych w ujęciu inżynierii ruchu

cases neither maritime administration nor shipowner are notified. However, if incident consequences $S_{c}>1$, then a salvage operation has to be arranged.

Accidents can be divided into two groups, depending on whether loss of life is at stake or not:

- accidents where the probability of loss of human life is low;

- accidents where the probability of loss of human life is high.

Risk assessment is made by one of the two methods, depending on the type of accident:

1) Incidents and accidents that do not cause loss of life are analyzed by considering the risk involved in making a specific manoeuvre or action (fairway passage, port entry, turning, discharge etc.). Acceptable risk in an analysis of such manoeuvres or actions

$$
R_{a k c}=7 \cdot 10^{-3} \text { yearly }
$$

Accidents where there is a high probability of fatalities is analyzed by using the concept of risk acceptable on an individual basis for shipping or risk acceptable socially (for a group of people). Acceptable risk in the analysis of such manoeuvres is adopted depending on the predicted (possible) number of fatalities [Gucma L. 2009].

The risk acceptable individually in in shipping ranges as follows [Gucma L. 2009]:

- for a crew member $E_{a k c}=10^{-3} \div 10^{-4}$ yearly;

- for a passenger $E_{a k c}=10^{-4} \div 10^{-5}$ yearly.

The risk acceptable socially (by a group) depends on the number of fatalities and oscillates around $E=10^{-4} \div 10^{-8}$ yearly [Gucma L. 2009].

\section{Summary}

The following conclusions can be drawn from a comparison of the two methods for the determination of safe manoeuvring area parameters:

1) Both methods of waterway system design have been verified and practically implemented [Gucma S et al. 2008; Gucma S. 2012].

The determinististic-probabilistic method permits to precisely examine and compare position determination systems to be used in the examined waterway. This feature distinguishes the method among other deterministic (empirical) methods. The navigational risk method has been widely used in ship movement simulation tests as a method for analysis and interpretation of simulation test results.

\section{Literature}

[1] Gucma L. (2009) „Wytyczne do zarządzania ryzykiem morskim”. Wydawnictwo Naukowe Akademii Morskiej w Szczecinie, stron 125, ISBN 978-83-89901-42-2.

[2] Gucma S. (2001) „Inżynieria ruchu morskiego”. Wydawnictwo: Okrętownictwo i Żegluga Gdańsk, stron 179, ISBN 83-908796-6-2. 
[3] Gucma S. (2004) „Nawigacja pilotażowa”. Wydawnictwo: Fundacja Promocji Przemysłu Okrętowego i Gospodarki Morskiej Gdańsk, stron 152, ISBN 83919488-5-4.

[4] Gucma S. (2010) „Reliability level of safe manoeuvring area”. Scientific Journals Maritime University of Szczecin, No 20(92), pp. 41-44, ISSN 17338670 .

[5] Gucma S. (2012) „Determination of optimal waterway system parameters and operating conditions for LNG Tanker operation in the port of Świnoujście". Scientific Journals Maritime University of Szczecin, No 30(102)2012, pp. 5260, ISSN 1733-8670.

[6] Gucma S., Gucma L., Zalewski P. (2008) „Symulacyjne metody badań w inżynierii ruchu morskiego". Wydawnictwo Naukowe Akademii Morskiej w Szczecinie, stron 224, ISBN 978-83-89901-29-3.

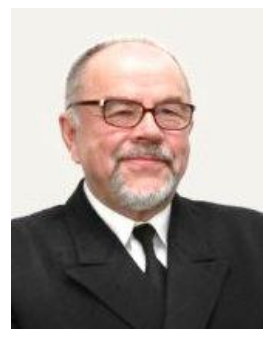

Professor Stanistaw Gucma, Master Mariner, is professor at the Maritime University of Szczecin. He is the creator of the new scientific discipline in Poland: marine traffic engineering. An author of 11 books and over 170 scientific publications on the subject. Professor Gucma has been in charge of more than 120 research projects. Most of them were implemented in Poland and EU countries. Some projects were related to the largest maritime investments in Poland. A member of the Transport Committee of the Polish Academy of Sciences (PAN), Academy of Engineering in Poland and the Transport Committee of Russia. 
The traffic engineering approach to problems of sea waterway system design Problemy projektowania systemu morskich dróg wodnych w ujęciu inżynierii ruchu 